\title{
ANALISIS POTENSI PENDAPATAN PERUSAHAAN DAERAH MAKASSAR RAYA
}

\author{
Abdul Talib Mustafa \\ Fakultas Ilmu Sosial Dan Ilmu Politik, Universitas Indonesia Timur \\ abdul.talib@uit.ac.id
}

\begin{abstract}
ABSTRAK
inPenelitian ini bertujuan memberi gambaran atas potensi Perusahaan Daerah Pasar Makassar Raya, faktor yang mendukung pengembangan potensi dan cara mengembangkan kapasitas PD. Pasar Makassar Raya. Penelitian bersifat deskriptif kualitatif. Data dikumpulkan melalui studi dokumen dan wawancara dengan para informan dengan menggunakan panduan wawancara. Pengolahan data dilakukan menggunakan SWOT Analisis. Hasil penelitian menunjukkan bahwa potensi peningkatan penerimaan PD. Pasar Makassar Raya dapat dikelompokkan ke dalam empat kategori. Pertama, yakni kurang dari atau sama dengan 5\% (5\% s) dengan potensi 4,34\%. Kedua yakni antara 5\% - 10\% dengan potensi $8,69 \%$. Ketiga, yakni antara $10 \%$ - 20\% dengan potensi $21,73 \%$, serta di atas $20 \%$ $(20 \% \geq)$ dengan potensi $65,24 \%$. Terdapat lima faktor penentu peningkatan penerimaan PD. Pasar Makassar Raya, yakni a) komitmen bersama seluruh karyawan, b) kepemimpinan yang kondusif, c) penataan peraturan perusahaan, d) peningkatan kekuatan dan menekan kelemahan, dan e) penataan kelembagaan perusahaan. Untuk mendorong peningkatan pendapatan PD. Pasar Makassar Raya dari sudut pandang manajemen stratejik terdapat tiga faktor yang perlu mendapat perhatian, yakni memperkuat komitmen seluruh karyawan, menumbuhkan kepemimpinan pada semua level, serta menata peraturan perusahaan.
\end{abstract}

\section{Kata Kunci : Potensi, Pendapatan, Perusahaan Daerah}

\section{PENDAHULUAN}

Dalam pandangan Kamaluddin (2001), perusahaan daerah memiliki dua fungsi. Pertama, yakni memberi pelayanan kepada masyarakat sesuai tugas pokok dan fungsinya dan kedua memberi dukungan bagi pengembangan ekonomi daerah. Fungsi kedua ini dapat berbentuk dorongan perusahaan daerah terhadap perkembangan ekonomi lingkungan dan kontribusi langsung bagi Pendapatan Asli Daerah.

Dalam upaya memaksimalkan pelaksanaan dan hasil dari kedua fungsi tersebut, setiap perusahaan daerah dihadapkan pada faktor yang mendukung dan penghambat. Karena itu, dalam mengevaluasi perkembangan suatu perusahaan daerah pendalaman atas faktor pendukung dan penghambat ini sangat penting di kedepankan.

Bagi PD. Pasar Raya Makassar diduga bahwa terdapat potensi yang dapat digali dalam meningkatkan penerimaan perusahaan ini. Masalahnya kemudian, untuk meningkatkan penerimaan perusahaan dari potensi dimaksud juga berkonsekuensi pada kemampuan perusahaan untuk mengatasi hal tersebut atau terhadap kemampuan koordinasi perusahaan daerah dengan stakeholders.

Dalam kaitan itu, pendalaman secara berkala atas potensi tersebut beserta prasyarat-prasyarat yang mesti dipenuhi untuk merealisasikan penting dilakukan. mu Politik, Fakultas Ilmu Sosial dan Ilmu Politik
Universitas Indonesia Timur. 
Dari sini kemudian dapat menjadi masukan bagi pimpinan daerah dan bagi manajemen perusahaan untuk menetapkan kebijakan strategis dan pola operasional perusahaan.

\section{Peran Perusahaan Daerah}

\section{Keberadaan perusahaan daerah tentu tidak terpisahkan dari keberadaan} Pemerintah Daerah itu sendiri. Diantara yang mendasar bahwa Pemerintah Daerah dibentuk untuk mencapai tujuan tertentu. Hal tersebut dinyatakan dalam klausul menimbang Undang-Undang Nomor 23 Tahun 2014 tentang Pemerintahan Daerah. Ditetapkan bahwa arah yang ingin dicapai berupa "mempercepat terwujudnya kesejahteraan masyarakat melalui peningkatan pelayanan, pemberdayaan, peran serta masyarakat, serta peningkatan daya saing daerah dengan memperhatikan prinsip demokrasi, pemerataan, keadilan, dan kekhasan suatu daerah dalam sistem Negara Kesatuan Republik Indonesia".

Dalam kaitan itu, salah satu peran yang diharapkan dari Perusahaan Daerah adalah proaktif sebagai pelaku ekonomi di tingkat daerah. Hal tersebut sejalan dengan pandangan Kamaluddin (2001) bahwa Perusahaan Daerah tentunya diharapkan berperan aktif, yaitu ikut menjadi penggerak bagi perekonomian daerah antara lain melalui kegiatan usaha dalam rangka memenuhi kebutuhan masyarakat baik barang, maupun jasa, sekaligus sebagai salah satu sumber Pendapatan Asli Daerah (PAD) yang potensial.

Peran tersebut berupa pemberian pelayanan barang atau jasa kepada masyarakat dan juga peran dalam memberi kontribusi bagi Pendapatan Asli Daerah. Namun, perkembangan tentang Perusahaan Daerah ini secara nasional belum menunjukkan kondisi yang menggembirakan (Wibowo, 2010).

Pada Pelita I, jumlah Perusahaan Daerah tercatat sebanyak 122 unit, dan Akhir Pelita IV atau sekitar 20 tahun kemudian, Perusahaan Daerah secara nasional telah berjumlah 491 unit. Kemudian pada tahun 1996, jumlah Perusahaan Daerah ini menjadi 651 unit.Perkembangan terakhir oleh Kementrian Dalam Negeri mencatat jika Perusahaan Daerah ini telah mencapai 1.174 unit.

Tapi ternyata peningkatan jumlah Perusahaan Daerah yang begitu pesat tersebut belum diikuti dengan peningkatan kualitas pengelolaannya (Wibowo, 2010). Tercatat jika dari ribuan Perusahaan Daerah ini, sekitar 50 Perusahaan Daerah atau hanya $4,26 \%$ yang terdaftar. Demikian juga, kontribusi penerimaan labanya terhadap PAD di daerah baik pada tingkat provinsi maupun kabupaten/kota relatif masih rendah. Laporan pada Kementrian Keuangan mengemukakan bahwa kontribusi penerimaan bagian laba BUMD terhadap PAD pada Pemerintah Provinsi mencapai 3,69\%, sedang kontribusi penerimaan bagian laba BUMD terhadap PAD Pemerintah Kabupaten/Kota rata-rata 7,51\%.

Rendahnya kinerja Perusahaan daerah ini disebabkan oleh berbagai permasalahan. Menurut Devas dkk (1989) dan Tjager dkk (2003) serta Yuwono (2001), diantara permasalahan tersebut adalah landasan hukum yang belum relevan, belum memiliki visi dan strategi bisnis yang relevan, kuatnya campur tangan Pemerintah Daerah, kualitas manajemen yang belum profesional, akses modal yang terbatas, kesulitan akuntabilitas keuangan, serta kemampuan kemitraan yang terbatas.

Fakultas Ilmu Sosial dan Ilmu Politik, Universitas Indonesia Timur. 
Kinerja Perusahaan Daerah juga dapat dianalisis dari perspektif laporan keuangan. Untuk analisis yang demikian ini, digunakan laporan keuangan, laporan laba-rugi, laporan harga pokok dan beberapa laporan keuangan lainnya sebagai sumber data atau bahan analisis (Rangkuti, 2004).

Untuk penggunaan laporan Neraca keuangan misalnya, setidaknya terdapat 4 (empat) aspek yang dapat dianalisis. Keempat aspek tersebut adalah Net Working Capital (modal kerja), Inventory Turn Over (perputaran persediaan), rasio hutang, dan piutang (Rangkuti, 2004).

\section{Pengembangan Potensi Perusahaan}

Setiap perusahaan demikian halnya bagi perusahaan daerah dilihat dari peluang pengembangan, selalu dihadapkan pada 3 (tiga) kemungkinan (Notoatmojo, 2003). Pertama, yakni peluang atas pengembangan potensi yang dimiliki. Kedua, yakni perusahaan daerah tersebut berjalan normal. Ketiga, kemungkinan atas merosotnya perusahaan daerah tersebut.

Secara umum, pengembangan perusahaan menurut Notoatmojo (2003) dimaksudkan sebagai upaya membuat sesuatu yang belum ada atau dapat diartikan memperbaiki atau meningkatkan sesuatu yang sudah ada. Dengan demikian, pengembangan memerlukan suatu dukungan sarana atau fasilitas yang dapat mendukung pelaksanaan secara sistematis dan prosedural.

Dalam pandangan Kesumaningtias dkk (2013), bahwa program-program pengembangan kapasitas seringkali didesain untuk memperkuat kemampuan dan mengevaluasi pilihan-pilihan kebijakan mereka dan menjalankan keputusan- keputusannya secara efektif. Pengembangan kapasitas tersebut bisa meliputi pendidikan dan pelatihan, reformasi peraturan dan kelembagaan, asistensi finansial, teknologi dan keilmuan.

Untuk mengembangkan kapasitas suatu organisasi, termasuk organisasi perusahaan, paling minimal ada 3 (tiga) aspek yang perlu mendapat perhatian. Menurut Sedarmayanti (2000) ketiga aspek tersebut adalah sumberdaya nyata, sumberdaya tidak nyata, dan sumberdaya manusia.

Terdapat 4 (empat) hal yang dapat dicapai dalam pengembangan kapasitas ini. Menurut Kesumaningtias dkk (2013) keempat hal tersebut adalah mengakselerasi pelaksanaan desentralisasi sesuai dengan ketentuan yang berlaku, pemantauan secara proporsional tugas, fungsi, sistem keuangan, mekanisme dan tanggung jawab dalam rangka pelaksanaan pengembangan kapasitas daerah dan mobilisasi sumber dana pemerintah daerah dan lainnya, serta penggunaan sumber dana secara efektif dan efisien.

Dalam pengembangan kapasitas, terdapat berbagai dimensi dan fokus yang menjadi tekanannya. Menurut Grindel (1997), dimensi tersebut adalah pengembangan sumberdaya manusia. Dimensi ini fokus pada ketersediaan tenaga professional dan personil teknis, penguatan organisasi. Dimensi ini fokus pada sistem manajemen, meningkatkan kinerja dan fungsi spesifik mikrostruktur dan reformasi Kelembagaan. Dimensi ini fokus pada institusi dan sistem makrostruktur. Sedang jenis aktivitas masing-masing dimensi dan fokus tersebut di atas, lebih jelas disajikan pada tabel berikut ini.

Fakultas Ilmu Sosial dan Ilmu Politik, Universitas Indonesia Timur. 
Tabel 1 : Dimensi, Fokus dan Jenis Aktivitas

Pengembangan Kapasitas Organisasi

\begin{tabular}{|c|c|c|}
\hline Dimensi & Fokus & Jenis Aktivitas \\
\hline $\begin{array}{l}\text { Pengembangan } \\
\text { Sumberdaya } \\
\text { Manusia }\end{array}$ & $\begin{array}{l}\text { Ketersediaan } \\
\text { tenaga } \\
\text { professional } \\
\text { dan personil } \\
\text { teknis }\end{array}$ & $\begin{array}{l}\text { Training, sistem } \\
\text { upah, kondisi } \\
\text { kerja, } \\
\text { rekruitmen }\end{array}$ \\
\hline $\begin{array}{l}\text { Penguatan } \\
\text { Organisasi }\end{array}$ & $\begin{array}{l}\text { Sistem } \\
\text { manajemen, } \\
\text { meningkatkan } \\
\text { kinerja dan } \\
\text { fungsi spesifik } \\
\text { mikrostruktur }\end{array}$ & $\begin{array}{l}\text { Sistem Insentif, } \\
\text { pemanfaatan } \\
\text { personil, } \\
\text { leadership, } \\
\text { kultur } \\
\text { organisasi, } \\
\text { komunikasi, } \\
\text { struktur } \\
\text { manajerial }\end{array}$ \\
\hline $\begin{array}{l}\text { Reformasi } \\
\text { Kelembagaan }\end{array}$ & $\begin{array}{l}\text { Institusi dan } \\
\text { makrostruktur }\end{array}$ & $\begin{array}{l}\text { Aturan main, } \\
\text { rezim ekonomi } \\
\text { dan politik, } \\
\text { perubahan } \\
\text { kebijakan } \\
\text { hokum, } \\
\text { reformasi } \\
\text { konstitusional }\end{array}$ \\
\hline
\end{tabular}

Sumber : Grindel (1997)

Dari uraian tersebut di atas menurut Kesumaningtias dkk (2013), peningkatan kapasitas adalah sebuah proses untuk meningkatkan kemampuan individu, kelompok, organisasi, komunitas atau masyarakat, sistem untuk :

1. Menganalisis lingkungan.

2. Mengidentifikasi masalah, kebutuhan dan peluang.

3. Merumuskan pengembangan sesuai dengan identifikasi masalah dan kebutuhan.

4. Merancang rencana aksi.

5. Menggunakan secara efektif dan berkelanjutan sumberdaya untuk mengimplementasikan, memonitor, dan mengevaluasi rencana aksi.

6. Menggunakan umpan balik sebagai proses pembelajaran.

\section{Faktor Yang Berpengaruh Atas Kapasitas Perusahaan}

Menurut Riyadi (2005), terdapat lima faktor yang mempengaruhi pengembangan kapasitas perusahaan, yakni :
1. Komitmen
bersama
(Collective Commitmens).

2. Kepemimpinan yang kondusif (Condusive Leadership).

3. Reformasi peraturan.

4. Reformasi kelembagaan.

5. Peningkatan kekuatan dan menekan kelemahan.

Komitmen bersama, setidaknya dapat dilihat dalam 3 (tiga) bentuk. Pertama, yakni pada proses pengambilan keputusan (perumusan kebijakan perusahaan), pelaksanaan keputusan atau kebijakan, dan pada pengendalian keputusan atau kebijakan tersebut. Sedang kepemimpinan yang kondusif dapat dilihat pada 4 (empat) aspek. Pertama, pada penciptaan suasana bekerja yang memberi dorongan atau spirit. Kedua, pada penciptaan suasana yang memberi arahan. Ketiga, pada penciptaan suasana yang memberi ransangan untuk berprestasi. Keempat, pada penciptaan suasana kerja yang berhati-hati. Terkait dengan reformasi peraturan, ini dimaksudkan sebagai respon perusahaan atas dinamika perkembangan lingkungan, baik internal, maupun lingkungan eksternal. Karena itu, reformasi peraturan ini dapat dilihat pada seberapa responsif perusahaan melakukan adaptasi atas peraturan-peraturan yang ada atau yang dibutuhkan diproduksi atau direproduksi.

\section{Metode Penelitian}

$$
\text { Penelitian yang dilakukan }
$$
merupakan penelitian kualitatif, dengan

Fakultas Ilmu Sosial dan Ilmu Politik, Universitas Indonesia Timur. 
menjadikan PD. Pasar Makassar Raya sebagai sumber utama data. Perusahaan daerah ini berlokasi di Kecamatan Makassar, Kota Makassar.

Dalam penelitian ini ada 2 (dua) jenis data yang digunakan, yakni data sekunder dan data primer. Data sekunder merupakan data-data yang bersifat umum terkait dengan pengelolaan PD. Pasar Makassar Raya. Sedang data primer merupakan datadata yang lebih detail yang memberi dukungan atau sejalan dengan data sekunder. Untuk data sekunder diperoleh dari dokumen yang relevan dengan masalah yang dikaji. Sedang data primer diperoleh dari informan yang mengerti dan memahami seluk-beluk pengelolaan PD. Pasar Makassar Raya. Mereka adalah direksi, kepala bagian, kepala pasar, kolektor dan karyawan.

Data yang dibutuhkan dikumpulkan dengan 2 (dua) cara. Untuk data sekunder dikumpulkan melalui penelusuran dokumendokumen yang berisikan peraturan perundang-undangan dan laporan pengelolaan PD. Pasar Makassar Raya, dengan kata lain melalui studi dokumentasi. Sedang data primer dikumpulkan melalui wawancara dengan para informan. Kegiatan ini dilaksanakan dengan melibatkan para informan sebagai sumber data seperti telah dijelaskan di atas serta menggunakan panduan wawancara yang dibuat secara terstruktur.

Data yang dikumpul dianalisis dengan menggunakan pendekatan kualitatif. Tahapan analisis tersebut adalah pengelompokkan data sesuai topik atau temanya, mereduksi data, yakni tidak sesuai dengan fokus kajian ini, menganalisis hubungan antara sub topik dengan sub topik lainnya di dalam topik yang sama, menganalisis hubungan antara satu topik dengan topik lainnya, menginterpretasi hasil analisis per sub topik dan per topik serta menyimpulkan hasil interpretasi penelitian.

Untuk pelaksanaan analisis digunakan instrumen SWOT Analisis. Dengan analisis ini dapat dikemukakan kekuatan, kelemahan, peluang dan ancaman bagi upaya peningkatan kinerja perusahaan sesuai potensi yang ada (Salusu, 1996).

\section{Hasil Dan Pembahasan}

\section{Faktor Pendukung Peningkatan Pendapatan Perusahaan}

Untuk peningkatan pendapatan PD. Pasar Makassar Raya tersebut, dalam pandangan para informan terdapat lima faktor yang berpengaruh dan perlu mendapat perhatian. Pertama, yakni komitmen bersama seluruh karyawan, kedua adalah kepemimpinan yang kondusif, ketiga yaitu penataan peraturan perusahaan, keempat adalah penetaan kelembagaan perusahaan, serta kelima yakni peningkatan kekuatan dan menekan kelemahan.

Terhadap kelima faktor tersebut, sebanyak 9 orang atau $36 \%$ yang menyatakan faktor berpengaruh tersebut adalah komitmen bersama seluruh karyawan. Selanjutnya sebanyak 6 orang atau $24 \%$ yang menyatakan jika faktor berpengaruh tersebut adalah kepemimpinan yang kondusif, sebanyak 5 orang atau 20\% yang menyatakan faktor berpengaruh tersebut adalah penataan peraturan perusahaan, kemudian 1 orang atau 4\% yang menyatakan faktor berpengaruh tersebut adalah penataan kelembagaan perusahaan, serta 3 orang atau 12\% yang menyatakan

Fakultas IImu Sosial dan Ilmu Politik, Universitas Indonesia Timur. 
jika faktor berpengaruh tersebut adalah peningkatan kekuatan dan menekan kelemahan.

Dari kelima faktor yang berpengaruh terhadap peningkatan pendapatan PD. Pasar Makassar Raya, tiga faktor yang paling berpengaruh masing-masing adalah komitmen bersama seluruh karyawan, kepemimpinan yang kondusif, dan penataan peraturan perusahaan.

Selanjutnya, dari 9 informan yang menyatakan bahwa Komitmen Bersama Seluruh Karyawan sebagai faktor yang berpengaruh atas peningkatan pendapatan PD. Pasar Makassar Raya, maka terdapat 3 faktor yang penting mendapat perhatian dalam pengembangan PD. Pasar Makassar Raya. Ketiganya masing-masing adalah dalam pengambilan keputusan perusahaan dinyatakan oleh 3 orang atau 38,89\%, sebanyak 3 orang atau $38.89 \%$ yang menyatakan pada pelaksanaan keputusan dan sebanyak 2 orang atau 22,22\% yang menyatakan pada faktor pengendalian hasil keputusan.

Sedang dari 6 orang yang menyatakan bahwa kepemimpinan yang kondusif sebagai faktor berpengaruh atas peningkatan pendapatan PD. Pasar Makassar Raya, sebanyak 3 orang atau $50 \%$ yang menyatakan jika pemberian motivasi sebagai faktor yang penting mendapat perhatian. Kemudian, 2 orang atau 33,33\% yang menyatakan jika pemberian arahan untuk mencapai tujuan sebagai faktor penting untuk mendapat perhatian, dan 1 orang atau $16,67 \%$ yang menyatakan jika pemberian penghargaan dan sanksi sebagai faktor penting dalam meningkatkan pendapatan perusahaan.

Terhadap faktor penataan peraturan perusahaan sebagai sebagai unsur yang berpengaruh atas pendapatan PD. Pasar Makassar Raya, selanjutnya dinyatakan jika atas faktor ini yang penting mendapat perhatian adalah menyempurnakan peraturan yang telah ada.Ini menjadi pandangan 5 orang atau 100\% dari mereka yang berpandangan bahwa faktor penataan peraturan perusahaan sebagai unsur yang berpengaruh atas pendapatan PD. Pasar Makassar Raya.

\section{Besaran Potensi Peningkatan Pendapatan Perusahaan}

Data sekunder dan data primer menunjukkan jika masih terdapat potensi dalam meningkatkan pendapatan PD. Pasar Makassar Raya.Terhadap potensi tersebut, terdapat dua pokok masalah yang mesti dijelaskan dan diharap menjadi masukan dalam merumuskan, melaksanakan dan mengevaluasi kebijakan pengembangan perusahaan.

Masalah pertama, yakni seberapa besar sesungguhnya potensi yang bisa direalisasikan itu?. Kedua, seperti apa potensi dimaksud dapat diwujudkan?.

Laporan penerimaan PD. Pasar Makassar Raya priode 2013 - 2017 menunjukkan jika pertumbuhan penerimaan perusahaan ini terjadi pada angka Rp. 5.308.412.900,- di tahun 2013 menjadi Rp. 9.546.840.100,- pada tahun 2017. Ini berarti bahwa untuk kurun waktu tersebut terjadi peningkatan penerimaan sebesar Rp. 4.238.427.200,- atau sebesar 79,84\%, dengan pertumbuhan rata-rata penerimaan per tahun sebesar 19,96\%.

Untuk pertumbuhan rata-rata tahunan di atas, malah oleh penerimaan beberapa pasar yang dikelolah oleh PD. Pasar Makassar Raya masih jauh lebih besar dari

Fakultas IImu Sosial dan IImu Politik, Universitas Indonesia Timur. 
angka pertumbuhan tersebut. Misal untuk Pasar Terong, pada tahun 2013 mencatat penerimaan sebesar Rp. 623.942.000,kemudian pada tahun 2017 sebesar Rp. 1.255.406.000,- $\quad$ sehingga terdapat peningkatan pendapatan kurun waktu empat tahun sebesar Rp. 631.464.000,- atau meningkat $101,21 \%$ dengan peningkatan rata-rata penerimaan per tahun sebesar 25,30\%.

Pertumbuhan yang lebih meyakinkan malah terjadi pada penerimaan Pasar Butung. Tahun 2013 tercatat penerimaannya Rp. 219.419.000,- kemudian tahun 2017 menjadi Rp. 734.868.000,-. Pada priode 2013 - 2017 terjadi peningkatan penerimaan sebesar Rp. 515.449.000,- atau 234,92\% dengan pertumbuhan rata-rata penerimaan per tahun sebesar 58,73\%.

Namun tidak dapat dipungkiri jika masih terdapat beberapa pasar yang pertumbuhan penerimaannya masih rendah. Misal Pasar Kampung Baru, pada tahun 2013 tercatat dengan penerimaan sebesar Rp. 123.579.000,- kemudian pada tahun 2017 sebesar Rp. 196.258.000,-. Ini berarti bahwa kurun waktu 2013 - 2017 peningkatan pendapatan pasar ini sebesar Rp. 72.679.000,- atau meningkat 58,81\% dengan pertumbuhan rata-rata per tahun sebesar $14,70 \%$.

Demikian juga misalnya dengan Pasar Makassar Mall, pada tahun 2013 tercatat dengan penerimaan Rp. 736.836.500,kemudian pada tahun 2017 menjadi Rp. 905.212.000,- dengan peningkatan sebesar Rp. 168.375.000,- atau $22,85 \%$ dengan pertumbuhan rata-rata per tahun sebesar $5,71 \%$.

Dari keseluruhan pasar yang memberi kontribusi penerimaan, dapat dikemukakan bahwa rasio pertumbuhan rata-rata per tahun yang terendah yakni - $(3,6 \%)$ oleh Pasar Darurat Selatan. Sedang yang tertinggi adalah penerimaan dari tagihan langsung dengan peningkatan rata-rata yakni $103,36 \%$ per tahun.

Sejalan dengan data yang disajikan pada tabel di atas, prospek peningkatan pendapatan PD. Pasar Makassar Raya juga dapat dicermati dari pandangan yang disampaikan oleh para informan kajian. Dari 25 orang informan tersebut, 23 orang atau 92\% dari mereka yang menyatakan jika peluang peningkatan penerimaan tersebut masih terbuka.

Perkiraan besarnya peluang peningkatan penerimaan tersebut terpola menjadi 3, yakni yang berpandangan bahwa besarnya kurang dari 5\% sebanyak 2 orang atau 8,70\%, yang berpandangan bahwa besarnya antara 5\% hingga $10 \%$ sebanyak 14 orang atau $60,87 \%$, dan yang berpandangan bahwa besarnya peningkatan penerimaan tersebut lebih dari $10 \%$ sebanyak 7 orang atau $30,43 \%$.

Dengan menggabungkan data historis dengan pandangan para informan tersebut, maka prospek peningkatan penerimaan pasar yang dikelolah oleh PD. Pasar Makassar Raya dapat dibagi menjadi 4 (empat) kelompok, masing-masing dengan prospek peningkatan penerimaan : a) $5 \% \leq$, b) $5 \%-10 \%$, c) $10 \%-20 \%$, d) $20 \% \geq$. Pengelompokan jumlah serta unit pasar yang termasuk dalam kelompok prospek peningkatan penerimaan dimaksud dapat dilihat pada tabel berikut ini :

Fakultas IImu Sosial dan IImu Politik, Universitas Indonesia Timur. 
Tabel 2 : Prospek Peningkatan Penerimaan PD.

Pasar Makassar Raya prinsipnya memiliki potensi peningkatan pendapatan. Hanya saja potensi peningkatan tersebut relatif berbeda antara satu pasar

\begin{tabular}{|c|c|c|c|c|}
\hline No. & $\begin{array}{c}\text { Prospek } \\
\text { Peningkatan }\end{array}$ & $\begin{array}{c}\text { Jumlah } \\
\text { Pasar }\end{array}$ & $\%$ & Unit Pasar \\
\hline 1 & $5 \% \leq$ & 1 & 4,34 & Darurat Utara. \\
\hline 2 & $5 \%-10 \%$ & 2 & 8,69 & $\begin{array}{l}\text { Makassar Mall, } \\
\text { Pa'baeng- } \\
\text { baeng. }\end{array}$ \\
\hline 3 & $10 \%-20 \%$ & 5 & 21,73 & $\begin{array}{l}\text { Kampung Baru, } \\
\text { Sawah, Mandai, } \\
\text { Panakkukang. }\end{array}$ \\
\hline 4 & $20 \% \geq$ & 15 & 65,24 & $\begin{array}{l}\text { Terong, Butung, } \\
\text { Pannampu, } \\
\text { Kalimbu, } \\
\text { Kerung-Kerung, } \\
\text { Sambung Jawa, } \\
\text { Cendrawasih, } \\
\text { Maricaya, } \\
\text { Mamajang, } \\
\text { Pa'baeng-baeng } \\
\text { Timur, Parang } \\
\text { Tambung, Niaga } \\
\text { Daya, Darurat } \\
\text { Selatan, PK-5, } \\
\text { Tagihan } \\
\text { Langsung. }\end{array}$ \\
\hline & Jumlah & 23 & 100,00 & \\
\hline
\end{tabular}

dengan pasar lainnya, dan yang terbesar bahwa peluang peningkatan tersebut berada pada angka di atas $20 \%$. Selain itu, peningkatan penerimaan tersebut juga dipengaruhi oleh berbagai faktor yang akan dibahas berikut ini.

\section{Kekuatan Perusahaan}

Ada 5 (lima) faktor yang mempengaruhi peningkatan penerimaan PD. Pasar Makassar Raya. Kelima faktor tersebut adalah : a) komitmen bersama seluruh karyawan yakni 36\%, b) kepemimpinan yang kondusif yakni 24\%, c) penataan peraturan perusahaan yaitu $20 \%$, d) peningkatan kekuatan dan menekan kelemahan yakni $12 \%$, dan e) penataan kelembagaan perusahaan $4 \%$.

Dari kelima faktor tersebut yang paling dominan adalah faktor komitmen bersama seluruh karyawan.Ini berarti bahwa kekuatan utama PD. Pasar Makassar Raya terletak pada kolektivitas orang-orang yang diberi tanggung jawab oleh perusahaan dalam mengemban tugas dan tanggung jawabnya masing-masing.

$$
\text { Selanjutnya pengejawantahan }
$$
pelaksanaan tugas dan tanggung jawab tersebut disederhanakan pada 3 (tiga) aspek penting dari komitmen bersama karyawan ini.Aspek pertama terletak pada proses pengambilan keputusan, yakni 38,89\%, dan yang kedua pada pelaksanaan keputusan yakni 38,89\%, yang ketiga adalah aspek pengendalian keputusan yakni $22,22 \%$. jika terhadap seluruh pasar yang dikelolah oleh PD. Pasar Makassar Raya pada 
Ini berarti bahwa faktor komitmen bersama sebagai penentu peningkatan pendapatan PD. Pasar Makassar Raya ditentukan oleh tiga aspek.Ketiganya adalah komitmen bersama dalam pengambilan keputusan, kedua yakni komitmen bersama dalam pelaksanaan keputusan, dan ketiga adalah aspek komitmen bersama dalam pengendalian keputusan.

Dengan demikian dapat disimpulkan bahwa faktor penentu pertama peningkatan pendapatan PD. Pasar Makassar Raya terletak pada sejauhmana komitmen bersama para karyawannya dapat ditumbuh kembangkan. Menumbuh kembangkan komitmen bersama para karyawan PD. Pasar Makassar Raya tersebut harus dilakukan melalui proses pengambilan keputusan, pada pelaksanaan keputusan dan pada pengendalian keputusan. Karena itu, kata kunci berkaitan dengan faktor penentu pertama ini adalah iklim yang demokratis sebagai pilar penentu peningkatan pendapatan perusahaan.

Faktor kedua yang mempengaruhi peningkatan PD. Pasar Makassar Raya adalah kepemimpinan yang kondusif.Faktor ini dibangun dari tiga aspek kepemimpinan.Pertama yakni pemberian motivasi 50\%. Kedua, yaitu pemberian arahan 33,33\%, dan ketiga adalah pemberian penghargaan dan sanksi 16,67\%.

Ini berarti bahwa PD. Pasar Makassar Raya berpotensi meningkatkan pendapatannya jika di dalam perusahaan ini pada mereka yang berada pada posisi memimpin staf memiliki ciri sebagai pemimpin yang mampu menciptakan suasana kerja yang kondusif.Suasana kerja yang kondusif tersebut hendaknya ditandai oleh pemberian motivasi oleh pimpinan kepada bawahannya pada semua level, kemudian juga ditandai oleh pemberian arahan kepada bawahan dalam melakukan tugas dan tanggung jawabnya, serta pemberian penghargaan dan sanksi atas apa yang dikerjakan.

Dengan demikian, selain faktor komitmen bersama karyawan yang perlu dibangun PD. Pasar Makassar Raya, maka juga adalah faktor kepemimpinan yang kondusif. Faktor kepemimpinan tersebut hendaknya ditumbuhkan melalui pemberian motivasi oleh pimpinan kepada staf, pemberian arahan kepada bawahan, dan pemberian pemberian penghargaan atas prestasi yang dicapai dan pemberian sanksi atas penyimpangan-penyimpangan yang mengganggu kinerja perusahaan.

Faktor ketiga yang menentukan peningkatan pendapatan PD. Pasar Makassar Raya adalah penataan peraturan perusahaan. Faktor ini ditandai oleh perlunya penataan peraturan perusahaan yang telah ada.Penataan tersebut mesti dilakukan secara simultan sejalan dengan dinamika perkembangan perusahaan, dan respon para pemangku kepentingan atau pihak-pihak yang terkait.

Selain itu, juga tetap perlu mendapat perhatian dua faktor lainnya sebagai penentu peningkatan pendapatan perusahaan. Kedua faktor tersebut adalah peningkatan kekuatan dan menekan kelemahan serta faktor penataan kelembagaan perusahaan.

Namun demikian, dalam konteks manajemen stratejik terdapat tiga faktor pokok yang menjadi kekuatan perusahaan untuk dapat berkembang melalui peningkatan pendapatan. Ketiganya adalah: a) komitmen bersama seluruh karyawan, b) kepemimpinan yang kondusif dan c) penataan peraturan perusahaan.

Fakultas IImu Sosial dan IImu Politik, Universitas Indonesia Timur. 


\section{Kesimpulan}

1. Potensi peningkatan penerimaan PD. Pasar Makassar Raya dapat dikelompokkan ke dalam 4 (empat) kategori. Pertama, yakni kurang dari atau sama dengan $5 \%(5 \% \leq)$ dengan potensi 4,34\%. Kedua yakni antara 5\% - 10\% dengan potensi $8,69 \%$. Ketiga, yakni antara $10 \%-20 \%$ dengan potensi $21,73 \%$, serta di atas $20 \% \quad(20 \% \geq)$ dengan potensi $65,24 \%$.

2. Terdapat lima faktor yang menentukan peningkatan penerimaan PD. Pasar Makassar Raya. Kelima faktor tersebut adalah : a) komitmen bersama seluruh karyawan, b) kepemimpinan yang kondusif, c) penataan peraturan perusahaan, d) peningkatan kekuatan dan menekan kelemahan, dan e) penataan kelembagaan perusahaan.

3. Untuk mendorong peningkatan pendapatan PD. Pasar Makassar Raya, maka dari sudut pandang manajemen stratejik terdapat 3 (tiga) faktor yang perlu mendapat perhatian bersama pimpinan dan staf perusahaan untuk dioptimalkan. Ketiganya adalah memperkuat komitmen bersama seluruh karyawan, menumbuhkan kepemimpinan yang kondusif pada semua level, serta menata peraturan perusahaan terutama atas peraturan yang telah diberlakukan.

\section{Referensi}

Akhyadi, Ade Sadikin, 2013, Model dan Strategi Pengembangan BUMD di Kabupaten Subang, Kemitraan Universitas Pendidikan Indonesia dan Pemda Kab. Subang.
Devas.N, B. Binder, A. Booth, K. Davey, R. Kelly, 1989, Keuangan Pemerintah Daerah di Indonesia, UI Press, Jakarta.

Hirawan, SB, 1996, Analisis Kerja Badan Usaha Milik Daerah (BUMD), Kerjasama Depkeu, Depdagri dan Pemerintah Kalimantan Barat, Pemerintah Kotamadya Pontianak, dan USAID, Jakarta.

Kamaluddin, R, 2001, Peran dan Pemberdayaan BUMD Dalam Rangka Peningkatan Perekonomian Daerah, Majalah Perencanaan Pembangunan, Edisi 23 Tahun 2001.

Kesumaningtias, Adinda, Abdul Hakim, dan Mohammad Nuh, 2013, Pengembangan Kapasitas Perusahaan Daerah Pasar Kota Kediri Melalui Sistem Informasi Pasar, Jurnal Administrasi Publik (JAP) Vol. 3, No. 1, Hal. 49-54.

Kuncoro, M, 1995, Desentralisasi Fiskal di Indonesia, Majalah Prisma Nomor 4/1995, LP3ES, Jakarta.

Rangkuti, Freddy, 2004, Business Plan : Teknik Membuat Perencanaan Bisnis dan Analisis Kasus, PT. Gramedia Pustaka Utama, Jakarta.

Riyadi, Soeprapto. H.R, 2005, Reformasi Administrasi Publik, Program Pasca Sarjana Universitas Brawijaya, Malang.

Salusu, J, 1996, Pengambilan Keputusan Stratejik : Untuk Organisasi Publik dan Organisasi Non Profit, PT. Gramedia Widiasarana Indonesia, Jakarta.

Sedarmayanti, 2000, Restrukturisasi dan Pemberdayaan Organisasi : Untuk Menghadapi Dinamika Perubahan Lingkungan, CV. Mandar Maju, Bandung.

Waits, MJ, 2000, The Added Value of The Industry Cluster Approach to Economic Analysis : Strategy Development and Serice Delivery, Economic Development

Fakultas IImu Sosial dan IImu Politik, Universitas Indonesia Timur. 
Quarterly, Vol. 14, No. 1, Februaary, 35 -

50.

Wibowo, Yuli, 2010, Analisis Prospektif

Strategi Pengembangan Daya Saing

Perusahaan Daerah Perkebunan (Tesis),

Fak. Teknologi Pertanian, Universitas

Jember, Jember.

Yuwono, T, 2001, Manajemen Otonomi

Daerah : Membangun Daerah Berdasar

Paradigma Baru, Pusat Kajian Otonomi

Daerah dan Kebijakan Publik,

Universitas Diponegoro, Semarang. 